\author{
Ю. В. Ключик \\ аспірант кафедри кримінального права \\ Інституту права імені Володимира Сташиса \\ Класичного приватного університету
}

\title{
ДО ПРОБЛЕМИ КВАЛІФІКАЦІЇ ЗЛОЧИНУ, ПЕРЕДБАЧЕНОГО СТ. 220-2 КК УКРАЇНИ
}

Однією з найсуттєвіших проблем України є слабкість та нестійкість ї̈ фінансової системи, що потребує ефективної кримінально-правової охорони. Користуючись нестабільністю політичної обстановки у державі, активізувалися особи, які вчинюять злочини у сфері господарської діяльності, що становлять велику суспільну небезпеку для економіки будь-якої держави. Особливо ї̈ підкошують випадки кримінального банкрутства, які останнім часом почастішали.

Проблемам кримінальної відповідальності за злочини у сфері банкрутства присвячували свої роботи такі вчені, як П.П. Андрушко, І.Н. Бенедисюк, Н.О. Гуторова, Є.М. Васілін, О.О. Дудоров, О.Є. Звірко, А.М. Клочко, В.М. Кирилко, І.А. Клепицький, Б.Н. Колб, М.Й. Коржанський, 0.О. Круглова, Н.А. Лопашенко, В.Н. Лук'янов, Н.М. Ляпунова, І.Ю. Михалєв, М.І. Мельник, Р.О. Мовчан, О.І. Перепелиця, А.М. Ришелюк, В.В. Сташис, Є.Л. Стрельцов, М.В. Талан, В.Я. Тацій, М.I. Хавронюк, І.О. Харь. Проте деякі питання щодо кваліфікації цих злочинів залишаються остаточно не вирішеними та потребують подальшого наукового пошуку. Певну складність становить кваліфікація злочину, передбаченого ст. 220-2 Кримінального кодексу України (далі КК України).

Метою статті є дослідження актуальних питань щодо кваліфікації фальсифікації фінансових документів та звітності фінансової організації, приховування неплатоспроможності фінансової установи або підстав для відкликання (анулювання) ліцензії фінансової установи як злочинів у сфері банкрутства.

$\mathrm{Y}$ науці кримінального права під кваліфікацією розуміють юридичну оцінку злочину і встановлення (застосування) тієї кримінально-правової норми, яка найбільш повно описує ознаки цього злочину [1, с. 5]. Ознаки (елементи) злочинного діяння охоплюються поняттям «склад злочину». До цих ознак (елементів) належать такі: об’єкт, об'єктивна сторона, суб'єкт та суб'єктивна сторона злочину. Тобто кваліфікація злочинного діяння «Фальсифікація фінансових документів та звітності фінансової організації, приховування неплатоспроможності фінансової установи або підстав для відкликання (анулювання) ліцензії фінансової установи» (ст. 220-2 КК України) - це встановлення повноти відповідності його ознак ознакам норми, яка передбачає відповідальність за вчинення саме цього злочину.

Відповідно до ст. 220-2 КК України «Фальсифікація фінансових документів та звітності фінансової організації, приховування неплатоспроможності фінансової установи або підстав для відкликання (анулювання) ліцензії фінансової установи" кримінально караним є діяння, яке полягає у внесенні змін до документів або реєстрів бухгалтерського обліку або внесенні у звітність фінансової установи завідомо неповних або недостовірних відомостей про угоди, зобов'язання, майно установи, у тому числі те, яке перебуває в довірчому управлінні, чи про фінансовий стан установи, у підтвердженні такої інформації, наданні такої інформації Національному банку України, опублікуванні чи розкритті такої інформації в порядку, визначеному законодавством України, якщо ці дії були вчинені з метою приховування ознак банкрутства чи стійкої фінансової неспроможності або підстав для обов'язкового відкликання (анулювання) у фінансової установи ліцензії або визнання її неплатоспроможною [2].

Фальсифікація фінансових документів та звітності фінансової організації, приховування неплатоспроможності фінансової установи або підстав для відкликання (анулювання) ліцензії фінансової установи є одним із злочинів у сфері господарської діяльності. Визначаючи поняття та систему вказаних злочинних діянь, можна зазначити родовий та видовий об'єкти злочину, передбаченого ст. 220-2 КК України.

У теорії кримінального права об'єкт злочину характеризується як певні суспільні відносини (тобто відносини та зв'язки, що встановлюються між людьми в процесі життедіяльності) [3, с. 43], на які зазіхає той чи інший злочин. Відповідно до вертикальної класифікації виділяються загальний, родовий, видовий та безпосередній об'єкти злочинів, а за горизонтальною класифікацією - безпосередній основний та безпосередній додатковий (обов'язковий чи факультативний) [3, с. 47-49].

Що стосується поняття, сутності та системи господарських злочинів, то можна зазначити, що підходи до вирішення зазначених питань у вітчизняній правовій доктрині є неоднозначними. Так М.Й. Коржанський характеризував 
розглядувані злочини як зазіхання на суспільні відносини, що утворюють систему господарювання і визначають порядок виробництва, розподілу i використання матеріальних цінностей, благ i природних ресурсів [1, с. 289]. При цьому науковець не систематизував господарські злочини, а брав за основу їх розподіл у КК України, а також не вказував на можливість реалізації підприємницької діяльності.

B.M. Стратонов та O.C. Сотула визначають злочини у сфері господарської діяльності як передбачені кримінальним законодавством суспільно небезпечні діяння, що зазіхають на суспільні відносини, які складаються щодо виробництва, розподілу, обміну та споживання благ та послуг. При цьому як родовий об'єкт даних злочинів вказується група однорідних і взаємопов'язаних суспільних відносин у процесі нормальної господарської діяльності з виробництва, розподілу, обміну та споживання благ та послуг [4, с. 259]. Науковці поділяють господарські злочини на дев'ять основних груп: 1) злочини у сфері грошового обігу, валютного регулювання та валютного контролю (ст. ст. 199, 200, 207-209, 214); 2) злочини у срері мобілізації коштів до бюджетів та державних цільових фондів (ст. ст. 202, 204, 212, 212-1); 3) злочини у сфері розподілу і використання бюджетних коштів (ст. ст. 210,211$)$; 4) злочини у сфері обігу державного комунального майна (ст. ст. 233-235); 5) злочини у сфері забезпечення свободи господарської діяльності, недопущення монополізму і недобросовісної конкуренції (ст. ст. 206, 228, 229, 231-232); 6) злочини у сфері забезпечення прав і законних інтересів споживачів товарів і послуг (ст. ст. 217, 225-227); 7) злочини у сфері виготовлення і використання документів у господарській діяльності (ст. ст. 215, 216, 223, 224); 8) злочини, які вчинюються у процесі банкрутства суб'єктів господарської діяльності (ст. ст. 218-221); 9) інші злочини у сфері господарської діяльності (ст. ст. 201, 203, 205, 222, 231) [4, с. 260]. Далеко не всі з зазначених злочинів полягають саме у зазіханні на суспільні відносини щодо виробництва, розподілу, обміну та споживання благ та послуг. Прикладом можуть слугувати злочинні діяння, які зазіхають на бюджетну систему України.

Як передбачені кримінальним законодавством суспільно небезпечні зазіхання на врегульовані державою відносини у сфері господарської (підприємницької) діяльності з виробництва суб'єктами господарювання товарів та іншої продукції, виконання робіт, надання послуг та зазіхання на фінансову діяльність держави визначав господарські злочини П.П. Андрушко [5, с. 29]. Характеризуючи розглядувані злочини, автор виділяє серед них окремо такі, що зазіхають на фінансову діяльність, тоді як остання не охоплюється родовим об’єктом даних зазіхань.
Як родовий об'єкт злочинів, включених до сьомого розділу Особливої частини КК України, В.Я. Тацій, В.M. Кириченко та O.I. Перепелиця вказують суспільні відносини у сфері господарської діяльності, зміст яких характеризується тим, що вони виникають з приводу виробництва, розподілу, обміну та споживання товарів, робіт i послуг [6, с. 185]. Класифікуючи господарські злочини, науковці виділяють такі групи: 1) злочини у сфері кредитно-фінансової, банківської і бюджетної сфери України (ст. ст. 199, 200, 201, 204, 207, 208, 210, 211, 212, 212-1, 215, 216); 2) злочини у сфері підприємництва, конкурентних відносин та іншої діяльності суб'єктів господарювання (ст. ст. 202, 203, 203-1, 205, 206, 209, 209-1, 213, $214,228,229,231,232)$; 3) злочини у срері банкрутства (ст. ст. $218,219,220,221) ; 4)$ злочини у сфері використання фінансових ресурсів та обігу цінних паперів (ст. ст. 222, 223, 223-1, 223-2, 224, $232-1,232-2)$; 5) злочини у сфері обслуговування споживачів і захисту їхніх прав (ст. ст. 217, 225, $226,227)$; 6) злочини у сфері приватизації державного і комунального майна (ст. ст. 233, 234, 235) [6, с. 186-187]. У даному випадку, на наш погляд, доцільніше було б розділити перший пункт на злочини у сфері кредитно-фінансової та злочини у сфері бюджетної системи України.

Узагальнюючи наведене, можна дійти висновку щодо родового об’єкту розглядуваних злочинів, а також фальсифікації фінансових документів та звітності фінансової організації, приховування неплатоспроможності фінансової установи або підстав для відкликання (анулювання) ліцензії фінансової установи. Отже, господарські злочини зазіхають на суспільні відносини, які виникають у процесі реалізації господарської (підприємницької) діяльності з виробництва, розподілу, обміну та споживання продукції або благ, надання послуг та виконання робіт.

Як видовий об'єкт злочину, передбаченого ст. 220-2 КК України, слід вказати суспільні відносини у сфері виконання суб'єктами господарювання або фінансовими установами своїх фінансових зобов'язань. У такому разі безпосередній об'єкт злочину збігається з видовим. Оскільки реалізація об'єктивної сторони розглядуваного злочину полягає, зокрема, у внесенні змін до документів або реєстрів бухгалтерського обліку або внесенні у звітність фінансової установи завідомо неповних або недостовірних відомостей, то додатковими і обов'язковими об'єктами даного злочинного діяння мають виступати інтереси та нормальна діяльність вказаної фінансової установи чи суб'єкта господарювання.

Більшість злочинів у сфері господарської діяльності $€$ предметною. Відповідно до змісту ст. 220-2 КК України предметами фальсифікації фінансових документів та звітності фінансової 
організації, приховування неплатоспроможності фінансової установи або підстав для відкликання (анулювання) ліцензї фінансової установи є такі фінансові документи та документи щодо звітності фінансової організації:

1) документи бухгалтерського обліку;

2) реєстри бухгалтерського обліку;

3) документи (у будь-якій формі) щодо звітності фінансової установи.

Фінансово-господарська діяльність організації супроводжується виконанням численних операцій. 3 цією метою застосовується елемент методу бухгалтерського обліку документації, тобто основний спосіб спостереження за господарською діяльністю організації, спосіб їі первинного контролю. Документування є першим етапом бухгалтерського обліку, від якості, достовірності, повноти та оперативності якого залежить увесь процес обліку.

Відповідно до п. 44.1 ст. 44 Податкового кодексу України для цілей оподаткування платники податків зобов'язані вести облік доходів, витрат та інших показників, пов'язаних з визначенням об'єктів оподаткування та/або податкових зобов'язань, на підставі первинних документів, регістрів бухгалтерського обліку, фінансової звітності, інших документів, пов'язаних з обчисленням і сплатою податків і зборів, ведення яких передбачене законодавством.

Документ - це матеріальний носій інформації, що засвідчує факт здійснення господарської операції. Бухгалтерський документ розуміють як інформаційну основу бухгалтерського обліку, що включає первинні документи, облікові регістри, форми звітності [7, с. 11].

Первинним документом $є$ документ, який містить відомості про господарську операцію та підтверджує її здійснення (ст. 1 Закону України «Про бухгалтерський облік та фінансову звітність в Україні» від 16.07.1999 р. № 996-XIV) [8].

Облікові регістри - це носії спеціального формату (паперові, електронні) у вигляді відомостей, ордерів, книг, журналів, машинограм тощо, призначені для хронологічного, систематичного або комбінованого нагромадження, групування та узагальнення інформації з первинних документів, що прийняті до обліку [9].

До основних форм звітності належать такі: фінансова, податкова звітність, звітність з ССВ (єдиного соціального внеску), звітність з пенсійного збору, статистична звітність.

Реєстри бухгалтерського обліку - це носії інформації спеціального формату і будови, призначені для реєстрації, групування і узагальнення господарських операцій, оформлених відповідними первинними документами [10, с. 48].

3 об’єктивного боку злочин, відповідальність за який встановлюється у ст. 220-2 КК України, виражається у таких формах:
1) внесення змін до документів або реєстрів бухгалтерського обліку. Під таким внесенням слід розуміти будь-яку фальсифікацію останніх. Можна зазначити, що таке діяння має ознаки спеціального виду підроблення документів (ст. 358 або ст. 366 КК України). Внесення вказаних змін полягає у внесенні в дійсний офіційний документ (реєстр) даних, що не відповідають дійсності повністю або частково. Оскільки внесення таких змін є одним зі способів реалізації об'єктивної сторони даного злочину, вчинення зазначених дій повністю охоплюється ст. 220-2 та не потребує додаткової кваліфікації за ст. 366 КК України;

2) внесення у звітність фінансової установи завідомо неповних або недостовірних відомостей про угоди, зобов'язання, майно установи, у тому числі те, яке перебуває в довірчому управлінні, чи про фінансовий стан установи. У цьому контексті недостовірна інформація - це така інформація, що повністю або частково не відповідає дійсності. Неповні відомості - це відомості, які містять часткову інформацію, що перекручує зміст документа та спотворює факти;

3) підтвердження зазначеної інформації. Таке підтвердження має носити офіційний характер;

4) надання такої інформації Національному банку України (передача у визначеному законодавством України порядку);

5) опублікування даної інформації (таке опублікування має здійснюватись в офіційному виданні);

6) розкриття зазначеної вище інформації (якщо зазначені дії було вчинено в порядку, визначеному законодавством України).

Злочин, передбачений ст. 220-2 КК України, належить до злочинів 3 формальним складом. Він вважається закінченим з моменту вчинення дій, які полягають у внесенні змін до документів або реєстрів бухгалтерського обліку або внесенні у звітність фінансової установи завідомо неповних або недостовірних відомостей про угоди, зобов'язання, майно установи, у тому числі те, яке перебуває в довірчому управлінні, чи про фінансовий стан установи, у підтвердженні такої інформації, наданні такої інформації Національному банку України, опублікуванні чи розкритті такої інформації в порядку, визначеному законодавством України, незалежно від того, чи настали якісь суспільно небезпечні наслідки вчиненого.

Попри те, що законодавець у диспозиції ст. 220-2 прямо не вказує на можливість вчинення розглядуваного злочину спеціальним суб'єктом, до такого висновку можливо дійти шляхом тлумачення закону. Здійснити внесення змін до документів або реєстрів бухгалтерського обліку або внесення у звітність фінансової установи завідомо неповних або недостовірних відомостей про угоди, зобов'язання, майно установи, у тому числі 
те, яке перебуває в довірчому управлінні, чи про фінансовий стан установи, підтвердження такої інформації, надання такої інформації Національному банку України, опублікування чи розкриття такої інформації в порядку, визначеному законодавством України, може особа, яка має на те хист та можливості. Суб'єктом злочину, передбаченого ст. 220-2 КК України, може виступати осудна особа, яка досягла 16-річного віку та є засновником чи учасником суб'єкта господарської діяльності (юридичної особи) або фінансової установи чи його службовою особою (наприклад, директор, головний бухгалтер), інша особа, службовими чи професійними обов'язками якої охоплюється здійснення зазначених вище дій.

3 суб’єктивного боку даний злочин вчиняється винятково з прямим умислом. Винна особа усвідомлює, що вчиняє внесення змін до документів або реєстрів бухгалтерського обліку або внесення у звітність фінансової установи завідомо неповних або недостовірних відомостей про угоди, зобов'язання, майно установи, у тому числі те, яке перебуває в довірчому управлінні, чи про фінансовий стан установи, підтвердження такої інформації, надання такої інформації Національному банку України, опублікування чи розкриття такої інформації в порядку, визначеному законодавством України. Така особа розуміє, що це діяння є суспільно небезпечним. Про навмисний характер дій винного свідчить зазначений у диспозиції ст. 2202 КК України термін «завідомо» (внесення завідомо неповних або недостовірних відомостей).

Обов'язковою ознакою суб'єктивної сторони фальсифікації фінансових документів та звітності фінансової організації, приховування неплатоспроможності фінансової установи або підстав для відкликання (анулювання) ліцензії фінансової установи є наявність у винного спеціальної мети вчинення даного злочину - приховати ознаки банкрутства чи стійкої фінансової неспроможності або підстав для обов'язкового відкликання (анулювання) у фінансової установи ліцензії, визнання її неплатоспроможною.
Мотиви вчинення розглядуваного злочину можуть бути різними і на кваліфікацію не впливають.

Отже, на основі зазначеного вище можна дійти висновку, що чітке та правильне визначення кримінально-правових ознак злочину «Фальсифікація фінансових документів та звітності фінансової організації, приховування неплатоспроможності фінансової установи або підстав для відкликання (анулювання) ліцензії фінансової установи» сприятиме його правильній кваліфікації працівниками відповідних державних органів під час реалізації ними своїх службових повноважень.

\section{Jimepamypa}

1. Коржанський М.Й. Кваліфікація злочинів : навчальний посібник. Київ : Атака. 2007. 592 с.

2. Кримінальний кодекс України : Закон України від 05.04.2001 p. № 2341-03. URL: http://zakon1.rada.gov.ua.

3. Кримінальне право України. Загальна та Особлива частини : навчальний посібник / за заг. ред. B.М. Стратонова. Київ : Істина. 2007. 400 с.

4. Кримінальне право України. Загальна та особлива частина. : навчальний посібник / за заг. ред. В.М. Стратонова. Київ : Істина. 2007. 400 с.

5. Андрушко П.П. Злочини у сфері господарської діяльності за чинним кримінальним кодексом: проблеми систематизації, криміналізації та декриміналізації. Підприємництво, господарство і право. 1998. № 12. C. $18-25$.

6. Кримінальне право України. Особлива частина : підручник / Ю.В. Баулін, В.І. Борисов, В.І. Тютюгін та ін. ; За ред. В.В. Сташиса, В.Я. Тація. 4-те вид., переробл. і допов. Харків : Право. 2010. 608 с.

7. Тігова Т.М., Селіверстова Л.С., Процюк Т.Б. Аналіз фінансової звітності : навч. посіб. Київ : Центр учбової літератури. 2012.268 с.

8. Про бухгалтерський облік та фінансову звітність в Україні : Закон України від 16.07.99 р. № 996-XIV. Відомості Верховної Ради (ВВР). 1999. № 40. ст. 365.

URL: https://taxlink.ua/ua/normative_acts/zakonykraini-pro-byhgalterskij-oblik-ta-finansovy/.

9. Про затвердження Положення про документальне забезпечення записів у бухгалтерському обліку : Наказ Міністерства фінансів України. 24.05.1995. № 88 (зі змінами, внесеними згідно з наказами Міністерства фінансів). URL: https://zakon.rada.gov.ua.

10. Білуха М.Т. Теорія бухгалтерського обліку. Київ, 2000. 692 с. 


\section{Анотація}

Ключик Ю. В. До проблеми кваліфікації злочину, передбаченого ст. 220-2 КК України. - Стаття.

Статтю присвячено кримінально-правовому аналізу складу злочину «Фальсифікація фінансових документів та звітності фінансової організації, приховування неплатоспроможності фінансової установи або підстав для відкликання (анулювання) ліцензії фінансової установи" як одного із злочинів у сфері банкрутства та проблемам його кваліфікації.

Досліджуються актуальні питання щодо кваліфікації фальсифікації фінансових документів та звітності фінансової організації, приховування неплатоспроможності фінансової установи або підстав для відкликання (анулювання) ліценвії фінансової установи як злочинів у сфері банкрутства.

Наведено класифікацію злочинів, пов'язаних з банкрутством, в системі злочинів у сфері господарської діяльності. Досліджено сутність та систему господарських злочинів.

Визначено родовий, видовий, безпосередній та додатковий об'єкти злочину «Фальсифікація фінансових документів та звітності фінансової організації, приховування неплатоспроможності фінансової установи або підстав для відкликання (анулювання) ліцензії фінансової установи».

Встановлено, що родовими об'єктами даного злочину є суспільні відносини, які виникають у процесі реалізації господарської (підприємницької) діяльності щодо виробництва, розподілу, обміну та споживання продукції або благ, надання послуг та виконання робіт; видовими та безпосередніми - суспільні відносини у сфері виконання суб'єктами господарювання або фінансовими установами своїх фінансових зобов'язань; додатковими й обов'язковими об'єктами є інтереси та нормальна діяльність фінансової установи чи суб'єкта господарювання.

Охарактеризовано предмет злочину, передбаченого ст. 220-2, його об'єктивнусторону тасуб'єктивні ознаки.

У процесі проведеного дослідження автор доходить висновку, що чітке та правильне визначення кримінально-правових ознак злочину "Фальсифікація фінансових документів та звітності фінансової організації, приховування неплатоспроможності фінансовоі установи або підстав для відкликання (анулювання) ліцензії фінансової установи» сприятиме його правильній кваліфікації працівниками відповідних державних органів під час реалізації ними своїх службових повноважень.

Ключові слова: об'єктивні ознаки, суб'єктивні ознаки, предмет злочину, фінансові документи, реєстр бухгалтерського обліку, фінансова установа, завідомо неповні відомості, завідомо недостовірні відомості.

\section{Summary}

Kliuchyk Yu. V. To problem of qualification of crime, envisaged by the article 220-2 of Criminal Code of Ukraine. - Article.

The article is sanctified to the criminally legal analysis of corpus delict falsification of financial documents and accounting of financial organization, concealment of insolvency of financial institution or grounds for the review (cancellations) of license of financial institution, as one of crimes in the field of bankruptcy, and to the problems of his qualification.

Topical issues of qualification of falsification of financial documents and reporting of a financial organization, concealment of insolvency of a financial institution or grounds for revocation (license) of a financial institution's license as one of the bankruptcy crimes are investigated.

The classification of crimes related to bankruptcy in the system of crimes in the field of business activity. The essence and system of economic crimes are investigated.

Determined generic, specific, direct and additional objects of crime "Falsification of financial documents and reporting of a financial organization, concealment of insolvency of a financial institution or grounds for revocation (license) of a financial institution".

It is established that: the generic object of this crime is the social relations that arise in the course of the economic (business) activity in the production, distribution, exchange and consumption of products or goods, provision of services and performance of works; specific and direct - public relations in the sphere of performance by economic entities or financial institutions of their financial obligations; the additional mandatory is the interests and normal activities of the financial institution or entity.

The subject of the crime under Art. 220-2, its objective side and subjective features.

In the course of the research the author concludes that a clear and correct definition of the criminal-law features of the crime "Falsification of financial documents and reporting of a financial organization, concealment of insolvency of a financial institution or grounds for revocation (license) of a financial institution" will facilitate its proper qualification during the exercise of their official powers.

Key words: objective signs, subjective signs, article of crime, financial documents, register of record-keeping, financial institution, incomplete information, unreliable information. 